\title{
Inclusion and exclusion within a policy of national integration: refugee education in Kenya's Kakuma Refugee Camp
}

\section{Citation}

Bellino, Michelle J, and Sarah Dryden-Peterson. 2018. Inclusion and Exclusion within a Policy of National Integration: Refugee Education in Kenya's Kakuma Refugee Camp. British Journal of Sociology of Education 40, no. 2: 222-38.

\section{Permanent link}

http://nrs.harvard.edu/urn-3:HUL.InstRepos:41343910

\section{Terms of Use}

This article was downloaded from Harvard University's DASH repository, and is made available under the terms and conditions applicable to Open Access Policy Articles, as set forth at http:// nrs.harvard.edu/urn-3:HUL.InstRepos:dash.current.terms-of-use\#OAP

\section{Share Your Story}

The Harvard community has made this article openly available. Please share how this access benefits you. Submit a story. 
Inclusion and Exclusion within a Policy of National Integration: Refugee Education in Kenya's Kakuma Refugee Camp*

\author{
Michelle J. Bellino \\ University of Michigan \\ Sarah Dryden-Peterson \\ Harvard Graduate School of Education
}

Corresponding Author:

Michelle J. Bellino,

School of Education, University of Michigan

610 E. University Ave, Ann Arbor, MI 48109

E-mail: bellino@umich.edu

Grant number: This research was supported by the National Academy of Education/ Spencer Foundation Postdoctoral Fellowships, granted individually to each of the authors in years 2016 and 2015 respectively. Additional support was provided by the University of Michigan Office of Research, the Weatherhead Center for International Affairs at Harvard University, and the Harvard Graduate School of Education. 


\section{Inclusion and exclusion within a policy of national integration: refugee education in Kenya's Kakuma Refugee Camp}

This paper explores the impact of global policy shifts toward 'national integration' on schooling for refugee youth in Kenya. Based on interviews and classroom observations in Kakuma Refugee Camp, we theorize that integration manifests in a multidirectional, hierarchical manner as few refugees integrate up into government schools, while most integrate down into segregated camp schools. We examine how youth interpret and navigate these oppositional paths, imbued with assumptions about quality and status. We argue that global policy can foster structures for physical integration; however, social integration, integrally connected to protection and opportunity, depends on local strategies and practices, encompassing formal decisions about adapting policy, as well as embedded beliefs about the purposes of educating refugees and their long-term inclusion in host societies. This study responds to calls for deeper sociological attention to education and global migration, as states expand educational opportunities for refugee populations while negotiating educational rights amongst citizens.

Keywords: social integration, inclusion, educational quality, refugee, global education policy

\section{Introduction: education is not the same}

Between classes at a school in Kakuma Refugee Camp, in Kenya, Nasra and her classmates gathered in the shade and reminisced about their old schools near Nairobi. At the government schools where they completed primary education, the classrooms were less crowded, teachers arrived on time, and students learned. ${ }^{1}$ At the time, Nasra suspected that she was the only refugee enrolled in her school. She told her classmates and teachers that she was Somali Kenyan, asserting a national identity that she imagined would increase her social acceptance. Nasra found other ways to fit in as well. She explained, "If they [your classmates] see you are always alone, not talking with anyone, they will suspect you are a refugee." Pretending to belong was an effective social strategy, until Nasra's family could no longer afford to pay the school's tuition 
fees. Nasra returned to Kakuma to enrol in secondary school, where education was free. As we talked, the break between classes stretched into the next class period, but students remained scattered when no teacher arrived. Nasra pointed to this as an example of the lower quality education that refugees accessed in camps, where teachers were unmotivated, arrived late, and frequently missed classes. She concluded that at camp schools, 'The syllabus is the same, but the education is not the same.' Like most of her peers, Nasra recognized that schools located outside the camp, staffed by Kenyan teachers and attended by Kenyan students, were higher quality institutions, despite that curriculum was the same. Regardless of where one completed school, the credentials would also be the same, but the academic advantages of studying in a government institution would - according to Nasra and her peers — set one on a path of upward mobility closed to most refugee youth.

Historically, the United Nations High Commissioner for Refugees (UNHCR) promoted parallel education systems for refugee populations, advocating that displaced peoples should learn in ways that were as closely aligned as possible with schools in their country of origin (Dryden-Peterson 2011). Impressions of consistency underlie this policy approach, presuming that young people would have begun their educational careers in their countries of origin and would likely continue them there, once able to return home. In the context of increased global migration and protracted displacement, the educational needs of refugee youth have changed, and policy has shifted in response. In 2012, UNHCR launched a new global education policy of 'national integration,' shifting the focus away from the country of origin and to refugee students' access to national education systems in their host countries (UNHCR 2012). The policy shift posits that education is higher quality, more protective and sustainable, and more cost effective when refugees benefit from established national systems and materials such as curriculum, 
teacher training, government assessments, and accreditation. In addition to these structural rationales, the policy alludes to the potential for sociocultural integration by fostering social cohesion and sustainable livelihoods for refugees in their host countries (Dryden-Peterson et al., forthcoming).

In this paper, we explore how the policy priority to integrate refugees within national education systems is experienced by youth in Kenya's segregated refugee camp settings. Based on interviews and classroom observations, we examine what integration means to youth and how this policy shift shapes opportunities and limitations on sociocultural integration for refugee youth in their host country of Kenya. We theorize that educational integration for refugees manifests in a multidirectional, yet hierarchical manner, reminiscent of integration processes for (im)migrants in other national settings. Among refugee youth, there is a shared desired to integrate up, meaning out of the camp setting into what they perceive as higher quality government schools attended by Kenyans. However, leaving the camp to access government schools often comes at the cost of sociocultural integration and a need to obscure one's refugee status. We contrast this desired educational mobility with the more readily available opportunities to integrate down into the camp schools that youth identify as of lower quality, despite a level of sociocultural integration among fellow marginalized populations, including nationally-disenfranchised host communities. We explore how integrating up and down present particular structural and sociocultural advantages and challenges to young people's mobility and their senses of belonging in a country where they lack citizenship status.

The policy initiative of integration is intended to better serve refugee populations, and could facilitate future efforts across host country contexts, aiming to close the gaps between national and global obligations to uphold children's right to education (Dryden-Peterson and 
Hovil 2004). However, we find that implementing an integration policy in a segregated camp setting can exacerbate, rather than mitigate, youth experiences of exclusion. We conclude that global policy can foster structural integration in the form of access to national education systems. But sociocultural integration, integrally connected to protection, belonging, and future opportunities, is limited under this approach. This article illustrates how local beliefs and practices interact with global policy in both fostering, and hindering, the integration experiences of refugees. Additionally, we explore how experiences integrating up and down are influenced by, and at times reinforce, Kenya's broader continuum of social stratification along ethnic and class lines. In doing so, we respond to calls for deeper sociological engagement with education as it relates to global migration, citizenship regimes, and state mechanisms of stratification and control (Kennelly and Dillabough 2008, Koyama 2013; Pinson, Arnot, and Candappa 2010), exploring these ideas through the educational experiences of refugees in Kenya.

\section{Context: Kenya and Kakuma Refugee Camp}

UNHCR works with the Kenyan government and NGO partners to implement education for refugees. For refugees in urban areas, they implement the policy of integration in a setting where refugees and nationals live together; in settings of rural encampment, the site of our study, they implement the policy in a setting in which both refugees and nationals are largely isolated, from each other and from centres of power. Despite available opportunities for pre-primary, primary, and secondary education in Kakuma Refugee Camp, nearly half of school-age refugee children and youth remain out of school. Some are unable to enrol due to their age, inadequate documentation of prior schooling, or poor performance on gatekeeping national exams; others are reluctant to enrol given perceptions of poor quality schools, the opportunity costs of attending school, and a limited opportunity structure for refugees after school completion. 
The education of refugees in Kakuma is set within the educational landscape of Kenya. The Kenyan government introduced Universal Primary Education in 2003 and Universal Secondary Education in 2008. The 2010 Kenyan Constitution further safeguarded the right to education for all children residing in Kenya, regardless of citizenship status (Republic of Kenya 2012). The elimination of tuition fees led to increased enrolment (Lucas and Mbiti 2012), however children's right to education, particularly at the secondary level, continues to be directly denied in some cases due to (illegal) school fees, or indirectly constrained through costs associated with boarding, transportation, and required school supplies (Odour 2016). Like many countries where fee-free schooling was recently introduced, children from the poorest households are less likely to be enrolled than those from wealthier households (Lewin and Sabates 2012). In addition, rural areas lag far behind urban areas in learning outcomes (Uwezo 2016).

While refugees are isolated from the centers of power in Kenya, so too are the national populations to whom they are geographically closest. Turkana, where Kakuma is located, has some of the highest concentrations of poverty and lowest rates of access to education in Kenya (see Kenya National Bureau of Statistics and Society for International Development, 2013). The proximity of refugees and marginalized national populations has led to UNHCR policy that mandates communities "hosting" refugee populations also benefit from services designed for refugees. Though grievances in Kakuma between refugees and Turkana are not uncommon (Aukot 2003), the construction of Kakuma Refugee Camp has resulted in increased access to schools as well as other social and economic opportunities for host community members, who have been historically excluded from these state services. 


\section{Framing refugee integration}

Concepts of integration, and their implications for structural and sociocultural processes related to citizenship and belonging, are debated and considered theoretically and practically imprecise (Ager and Strang 2008; Stewart and Mulvey 2014; Strang and Ager 2010). An important distinction within the literature exists between structural integration into formal state systems such as education, health, and employment, and integration as a sociocultural experience of identity transformation, increased connectedness, and a sense of belonging (Korac 2003). Theories of integration are widely critiqued amongst educational researchers and practitioners in Western, industrialized receiving countries for their assimilatory assumptions that membership is unidirectional and spatially bound (e.g., Alba and Nee 2003; Waters and Jiménez 2005; Waters et al. 2010). The presumed setting for these debates is often one of structural integration. That is, conditions allow for access to services and legal rights (e.g., Gordon 1964; Park et al. 1925; Warner and Srole 1945), and thus integration is often problematically construed as a matter of individual choice (Jansen, Chioncel and Dekkers 2006; Morrice 2017). However, most refugees find exile in states that neighbour their country of origin (UNHCR 2017), most of which lack the stability and/or capacity of institutions to allow for structural integration. Moreover, the vast majority does not access pathways to citizenship in sites of exile (Nunn et al. 2015).

Even in settings where conditions are conducive to structural integration, research in the United States and Western Europe points to states' 'organized abandonment' (Gilmore 2011) of marginalized individuals and communities, including refugees (Alba and Foner 2014; Capps and Newland 2015; Milbourne 2002). Often (im)migrants and refugees in resettlement contexts access segregated and inequitable services, such as low-performing schools. They do not easily cultivate a sense of belonging in the majority culture; meanwhile, assimilatory pressures limit 
opportunities for 'cultural citizenship', which allows for 'the right to be different and to belong' (Rosaldo 1994, 402). Under these conditions, integration is not a linear, upward trajectory, but instead can create 'segmented' pathways, including not only the storied 'upward' mobility but also 'downward' toward persistent poverty and disenfranchisement (Koyama 2013; Morrice 2017; Portes 1998; Portes and Rumbaut 2001; Portes and Zhou 1993).

A growing body of literature has examined the ways that (im)migrant youth experience schools as sites of both inclusion and exclusion (Abu El-Haj 2015; Callahan, Muller and Schiller 2008; Hertzberg 2015; Jensen and Flanagan 2008; Kurban and Tobin 2009; McCarthy, RezaiRashti and Teasley 2009; Myers and Zaman 2009). At times, schools perform a dual process of "welcoming-unwelcoming” (Gitlin, Buendía, Crosland, \& Doubmia, 2003), which both invite immigrant students into the school community and simultaneously "unwelcome" them through acts of exclusion. Educational institutions reproduce difference through exclusionary expressions of national identity embedded in curriculum, as well as through everyday interactions. Through ethnography, Abu El-Haj (2015) documents the ways that immigrant youth's ethnic and religious identities are visibly stigmatized in US schools for not taking part in assimilatory practices such as reciting the Pledge of Allegiance to the American flag. Across studies, structural integration of non-native students into national schools often implies sociocultural assimilation, as school norms have historically privileged the beliefs and practices of dominant racial groups and middle and higher income families (Horvat, Weininger and Lareau 2003; Pinson, Arnot, and Candappa 2010). This integration of refugee students into assimilatory structures has been linked to academic and social isolation, as well as physical insecurity (Ager and Strang 2008; DrydenPeterson 2017; Karam, Monaghan and Yoder 2016; Maber 2016). Further, (im)migrant populations are often funnelled into lower quality, high poverty schools (Bartlett and Ghaffar- 
Kucher 2013; Milbourne 2002) and learn apart from long-time residents, affluent, and/or white students. In both of these situations, integration can be oriented 'downward,' toward permanent poverty, racial isolation, and cultural exclusion.

In contrast, some schools uniquely cater to 'newcomer' student populations, developing inclusive practices and responsive curriculum. In recent work, particularly a set of studies with the Internationals Network for Public Schools, researchers find that schools designed to take into consideration the sociocultural needs of migrant populations correlate with positive social and academic outcomes for students and their families (Bajaj, Canlas and Argenal 2017; Bajaj and Bartlett 2017; Mendenhall, Bartlett and Ghaffar-Kucher 2017). These studies demonstrate that social belonging, a component of sociocultural integration, coupled with high quality education can overcome negative effects of segregation. However, this research takes place in the U.S., where legal migrants are on a path toward legal citizenship and are, theoretically, able to access both structural and sociocultural integration outside formal school environments, in particular, they are not confined to camp settings as our research participants are. While accounting for the distinct conditions refugees encounter in Kenya as their country of first asylum, we draw from these studies, which point to promising educational practices in geographically segregated settings.

Cross-national research reveals that structural integration in educational institutions is, at times, employed as a socializing mechanism that facilitates national inclusion for (im)migrant children. In other cases, it signifies that a sense of connectedness to the host country has been established, obligating states to include (im)migrant children in services such as public education (Bartlett 2015). This tension echoes debates over whether citizenship should be conceived as a 'tool or reward' in the process of integration (Jurado 2008). The Kenyan state goes to lengths to 
communicate that citizenship is not a reward for refugees who display high levels of attachment to Kenya. Even refugees born in Kenya, legally considered citizens after seven consecutive years of residency, are unlikely to attain citizenship. Likewise, access to opportunities for structural integration beyond basic education remains limited. Thus, the institutions and policies that govern refugees' lives are not aligned with educational integration policies. Widespread beliefs amongst educational staff are at odds with this policy, as many continue to believe that refugees' futures will be 'elsewhere' (Dryden-Peterson et al., forthcoming). Refugee youth recognize the irony that their Kenyan education is likely more valuable if they migrate outside of, rather than stay within, Kenya (Bellino in press).

Under the 1951 Refugee Convention, to which Kenya is signatory, and under national law, refugees have the rights to mobility and work in Kenya. In practice, however, neither of these rights is upheld. As such, refugees settle outside camps at their own risk, often in urban areas, where they are subject to routine harassment by police and other state actors (Human Rights Watch 2002). Moreover, settling amid nationals rarely implies sociocultural integration (Kagwanja, Odiyo and Ndege 2001; Karanja 2010). Researchers found that the large majority of urban refugees 'did not feel assimilated into the fabric of Nairobi society' (Pavanello, Elhawary and Pantuliano 2010, 8); meanwhile children, like Nasra, chose to 'hide their refugee status and speak and act like Kenyans to avoid stigma and discrimination' (25).

\section{Research methods}

This study is based on field-based data collected between June 2014-May 2017. We draw from a series of semi-structured interviews with staff members of organizations working on refugee education in camps and urban areas $(n=26)$; refugee and national teachers $(n=36)$; and refugee 
students attending or recently graduated from secondary schools $(n=33)$. Interviews with organizational actors focused on their interpretations of the UNHCR Global Education Strategy, approaches to implementation and local adaptation, and beliefs about the purposes of education for refugees. Interviews with teachers focused on their approaches to educating refugee children and how they interpreted and made use of the principles of the Strategy. Across interviews with teachers, we also asked about the futures they envisioned for their students and how they thought about their teaching in preparation for those futures. Interviews with students explored educational experiences within and outside of the camp setting, with particular attention to interactions between everyday school experiences and messages about migration, future aspirations, and educational opportunities.

Interviews were supplemented by participant observation in primary and secondary classrooms. Observations also allowed for deeper understanding of how Kenyan identity, refugee status, and the prospects of social belonging in Kenya were conveyed and experienced through everyday school practices. Classroom observations encompassed a range of content areas, as well as unstructured time during the school day among teachers (e.g., staff meetings, breaks, grading sessions) and students (e.g., study periods, lunch, after-school programming).

Data collection and analysis took place simultaneously, with daily observations and emergent analysis documented in field notes and memos. Interviews were conducted in English, audio recorded when possible, and transcribed. All data was subsequently coded by at least one author, employing a multi-stage coding process. Initial phases of analysis aimed for close alignment with policy frameworks outlined in the Strategy. During this early stage, we noticed variance in how the principle of integration was defined, envisioned, and enacted by various actors. In later phases, we further differentiated between experiences set in camp schools where 
structures and curriculum were the primary locus of integration policies, and government schools outside camps where, in addition to structural elements, refugee students learned alongside Kenyan students. We sought a grounded understanding of students' and teachers' interpretations of these various experiences set in distinct school settings.

\section{Findings}

In this section, we outline two principal approaches to policies of national integration, while considering how these approaches are experienced and interpreted by refugee youth. The first approach, which we call integrating down, is the most common form of integration experienced in settings of encampment, where students access what they define as lower quality education, yet in an environment that aims to be inclusive and supportive of refugee needs. Leaving the camp and integrating up to pursue education in a government school is one of the sole opportunities for refugee youth to interact with a diverse population of Kenyan nationals, though these migrations often encompass challenges to youth protection and belonging.

The binary distinction between integrating $u p$ and down inevitably reduces the complexity of lived experience, which is mutable, context-dependent, and not homogenously "better" or "worse," according to one's trajectory. Organizing approaches to integration along multidirectional and hierarchical dimensions is intended as an analytic tool to compare different modes of integration, strategies undertaken by refugees who navigate between them, and the advantages and disadvantages accumulated through both experiences. Moreover, the hierarchical elements emphasized in this analytic reflect what we found to be shared assumptions amongst refugee youth, teachers, and organizational staff. Importantly, the impression of integrating $u p$ or down through education is rooted in the perspective of a refugee vis-à-vis the host country, thus 
mobilizing existing social hierarchies within Kenya. Throughout the text, we note important exceptions where these binaries became less clearly defined in practice, aiming to illustrate the complexity of integration experiences. Finally, we argue that these constructs are relational, in that processes of integrating up simultaneously construct, and are constructed by, impressions of integrating down.

\section{Integrating down}

For many children and youth, camp schools were their first exposure to formal education. For some refugees, the absence of education in their country of origin, coupled with awareness that educational opportunities were available in Kakuma, played a role in their displacement (Epstein 2010). For these students, merely accessing schools with permanent infrastructure, paid teaching staff, and learning materials — despite shortages — was a step up from the conditions in their country of origin. Yet within the landscape of Kenya, refugee young people also came to understand that the quality of education in Kakuma was lower, when compared with schools accessible to national citizens outside the camp context. Like Nasra, they understood that despite teaching the same curriculum, the quality of education varied depending on context.

Camp schools in Kenya aim for $10 \%$ of student vacancies to be filled by non-refugee nationals coming from the host community. However, as the refugee population has grown, Kakuma schools have become overcrowded. Classroom conditions are so poor that, a UNHCR education officer explained, 'the host community...don't want to send their children here when they see how it is.' Teachers concluded that Kenyan students who attended camp schools were from extremely disadvantaged families, because, as one teacher explained, 'no one wants to attend school in a refugee camp.' 
School leaders and classroom teachers rarely knew with certainty the national or ethnic backgrounds of their students. In cases where Kenyan students were attending school alongside refugee students, teachers often spoke of the economic and social similarities across these groups, rather than the marked differences in their legal status or potential future opportunities. $\mathrm{Kuku}$, a refugee teacher who grew up in Kakuma explained that these groups have different needs in general, 'but here at school they are equal.' Another agreed, 'There's no difference between the Kenyans and refugees... Some live inside the camp. The others, they live around the other side.' Elizabeth, a Kenyan teacher, explained that both groups share many of the same experiences with poverty, such as malnourishment, long walks to school, and few resources at home. Across schools, teachers and program staff maintained that intergroup conflicts between refugee and host community students were rare and less worrisome than conflicts between refugee groups. These comments suggest that when social differences became salient among students, it was not one's legal status in Kenya that triggered conflict but rather longstanding ethnic tensions carried across borders. An educational officer insisted that refugee and national students 'are good friends. They are one, at the end of the day... School is a place that makes them be one.' This idea of togetherness and social harmony, of 'being one' within the confines of marginalization, supported notions of integrating down.

The challenges refugee young people faced in camp schools were not substantively different than in most government schools in Kenya, or across many states in sub-Saharan Africa. Widespread challenges are evident in settings where access has expanded rapidly in the absence of resources to support quality education (Lewin 2009; Murnane and Ganimian 2014). Yet students in Kakuma who had been enrolled in government schools experienced the differences of quality acutely. Amaani reasoned that in non-camp schools, 'you pay school fees 
and so teachers come on time. In camp schools, if they don't feel [like it], teachers don't come. No one controls them.' Amaani was describing a common practice in government schools, where teachers charged extra tuition fees. Despite this practice being illegal, it is widespread (Bray 2009), with more than $87 \%$ of students in Kenya paying extra tuition in 2000 (Paviot, Heinsohn and Korkman 2008).

Students perceived teachers in the camp schools to be 'unprofessional' and 'untrained.' The majority of teachers in camp schools are refugees who completed high school in Kenya, earning 'incentive' pay rather than a salary, given their differential work status. Youth who questioned the value of school explained, 'one day you graduate Form 4, and the next day you are a teacher in that same class.' UNHCR collaborated with partners to expand training opportunities for educators; still, the reality was that most refugee teachers completed little more than a five-day training. Students conceived of the presence of refugee teachers in their school as devaluing their education, even though teaching would be one of the only employment opportunities open to them upon their own graduation. In contrast, the inclusion of national staff presumably served to increase the quality of schools, both through direct contributions such as higher quality instruction and indirectly, as national staff were expected to mentor refugee teachers with less experience. While national staff was espoused as key to instructional improvement, refugee teachers were often regarded as uniquely capable of understanding the refugee student experience. During community events, teachers were put on display to showcase these particular roles. This disparity between the positioning of refugee and national educators powerfully reasserted the limits on refugee belonging, even in spaces that were created specifically to serve refugees. 
Conditions of camp schools made it difficult to foster close relationships between students and school actors. Teachers often grew frustrated with students' lateness, absence, and lack of demonstrable academic improvement, interpreting these expressions as ingratitude for the right to learn in exile. Frustrations often led to generalized, deficit-oriented comments about refugee students who presumably 'are not serious,' and growing resentment toward teachers who 'do not understand the refugee.' Refugee teachers exhibited both greater sympathy, and scepticism, toward students, understanding that 'they are inside the classroom, but their minds are outside.' For national teachers in particular, students' poor performance and frequent disciplinary issues became struggles over the implicit purposes of refugee education. During staff meetings, a recurrent concern vocalized by national staff was whether education in a camp school should privilege authentic teaching and learning, or 'covering the syllabus.' These conversations revealed concerns over how to teach the Kenyan syllabus to students who 'do not own the curriculum,' questioning the social purposes of learning Kenyan history, language, and geography. Uncertainties led some teachers to believe that they were diluting the curriculum, or 'teaching down,' as one teacher remarked. Occasionally, teachers appealed to national policy as a rationale for not adapting a practice to their students' needs, such as moving out of sequence on the syllabus, stating, 'This is not Kenyan policy.' These instances indicated a level of resistance and hesitation on the part of national teachers toward shifting the structures of integration to accommodate non-citizens.

Kenyans attending schools in Kakuma were acutely aware that they were attending a refugee school and, in most cases, that this was a consequence of their state's inability to guarantee free and universal access to basic, especially secondary, education for all citizens. They also understood, to varying degrees, that their identity as a member of a marginalized tribe 
had something to do with this. One student, Michael, explained, 'the government of Kenya is not caring [for] Turkanas. That's why you find a lot of Turkanas in refugee camp... They are housemaids in Somali [refugee] community, and they are citizens of this country [emphasis added].' Some Turkana students openly expressed appreciation for the presence of refugees in Kakuma. Ironically, they noted, services designed predominantly for refugees worked toward structural integration of the host community. One boy explained, 'In Kenyan schools, people pay a lot of money. And we find that in Kakuma here, people learn freely.' A Turkana community member who attended a camp secondary school recalled, 'when that school in the camp opened, I said, this is my chance.'

There were, however, mixed feelings about whether the construction of the refugee camp, associated social services, and surrounding economy benefited Turkanas to the extent that had been promised. For Patrick, attending school in Kakuma was his only option to continue postprimary education. Yet even in his appreciation for the chance to continue his schooling, he understood that he had a right to attend a higher quality institution and resented that he was forced to attend a refugee school. Originally selected to attend an elite National school, Patrick's family was unable to afford school-related expenses. Privately, Patrick lamented, 'I am a Kenyan, a Kenyan... This is a school for refugees.' Moreover, Patrick secretly believed that refugees had internalized a sense of superiority over Turkanas, learning from inequitable treatment of Turkanas by other Kenyans working in the area, tensions echoed in other work (Aukot 2003). He explained, 'You know, there is no respect between the refugee camp and the host community... They are saying, you are useless people, you are poor people.'

In conversations about post-secondary life, refugee youth often compared their lack of prospects to the educational and work opportunities presumably available to Kenyan citizens. 
But this logic was applied with caution toward their Turkana classmates, who refugees understood to have legal opportunities unavailable to them as non-citizens, while also recognizing barriers such as identity-based discrimination that would limit these opportunities. Abdo reflected on Turkana marginalization, 'These people [Turkanas] are feeling like they are refugees although they are in their own country, because they are abandoned by their own government.' Shared marginality and limited future prospects served to unite refugee and host community youth as subordinate members of Kenyan society, though tensions surfaced in particular when opportunity structures became available to one group and not the other.

In contrast to claims that students in camp schools appeared to belong to a homogenously disenfranchised group, teachers, students, and program staff easily distinguished between national and refugee teachers. Inequities between refugees and nationals and across Kenyan tribes became more visible amongst teachers, given greater ethnic diversity among teaching staff. For example, national staff from counties south of Turkana occupied most of the leadership positions in schools and related educational offices, and their voices and concerns regularly dominated school meetings. Within the staff room, teachers were often segregated by status, with nationals occupying fixed desks and refugee and Turkana teachers floating the room. In mornings and afternoons, refugees were expected to walk from their homes to the school while national staff was driven in agency vehicles. Refugee students routinely witnessed these power imbalances, which directly impacted their relationships with teachers and indirectly influenced their impressions of Kenyans and national-refugee dynamics more broadly.

\section{Integrating up}


In the above section, we demonstrated that despite efforts to integrate camp schools via curriculum, staff, and credentials, there are persistent beliefs that camp schools remain parallel structures of lesser quality. Contrasting experiences of integrating down, some refugee youth described processes of integrating up, accessing higher quality government schools, and experiencing temporary spatial mobility, away from the camp. As in the camp context, the sociocultural dimensions of integration are complex, involving both potential advantages and risks.

When refugees are awarded scholarships to attend government schools outside of Kakuma, they are typically accessing elite National institutions located in urban areas, chosen precisely because they provide high quality education. In addition to organizational support, families made selective investments in young people by privately funding opportunities to attend schools outside the camp, even when educational quality and academic gains were questionable. Given the financial costs associated with integrating up, families often invested in a single child's schooling outside the camp. The promise to integrate up was offered as an incentive and a reward for high academic performance. For example, Jok's cousin agreed to pay his school fees if he rose to the top of his class in his camp primary school. Jok now uses the same incentive structure with his younger siblings, rewarding the highest performing with access to a government school.

Opportunities to integrate up are unstable, often unsustainable, and severely limited. During times of uncertainty, financial and otherwise, families were forced to be more selective with educational investments. Organizations, depending on donor funding, shift the number of students and the level of support, and in some cases are forced to move students to closer or less expensive schools to reduce associated costs. Many young people experienced interrupted 
schooling due to preferences to integrate up into government schools and subsequent pragmatic necessities of integrating down into camp schools. Adut recalled the day she received news that her family would no longer be able to sponsor her education in an urban government school, where she was performing well. At seventeen, she had the choice to remain with her family in the city, in educational limbo, or move to the camp on her own to continue her education. Adut said to herself, 'I can't stay without going to school... The time would never be recovered. So I say, better I go to school and learn than I stay at home.'

Comparing non-camp schools to camp schools, nearly all students commented on the quality of instruction as signalled by the presence of teachers who were 'professionals.' Tuition fees — whether formally charged by private schools, or embedded in the illegal but widespread tuition practices of government schools - were an implicit measure of teacher quality. In contrast, students commonly viewed teachers in camp schools as 'unprofessional' and unmotivated. Eddie, a national student studying in a camp school remarked that fees at secondary schools outside the camp ensured teachers' accountability to students, "[In a government school], students...can tell their parents, this one is not coming, this one is not teaching well. And because they pay fees, they can sack them. Here ...teachers are like volunteers. We have no power."

Less frequently, organizational staff, students, and families mentioned sociocultural benefits of studying in a government school. On the other hand, most emphasized the challenges of adapting to a new social environment outside the camp. An educational staff remarked, 'For some of them, it is their first time outside the camp. Maybe it is their first time anywhere except Kakuma.' In reflecting on experiences studying in schools outside Kakuma, young people reported experiences of identity-based discrimination. Somali students in particular cited 
challenges such as finding time for prayer during school hours and adapting school uniforms to accommodate hijab. Others endured verbal abuse, being called terrorists or Al Shabaab, by both students and teachers. Ibrahim recalled that name-calling turned into physical bullying after school hours.

These experiences, attending schools alongside Kenyans, reinforced refugees' needs to shield their identity as a protective measure. Through everyday tribal identifications amongst Kenyan students, it became clear that refugees were not Kenyan and thus did not belong in the same social structure. Alier, strikingly tall and dark, realized that he was visibly different from Kenyans and many knew immediately that he was South Sudanese. His first week of secondary school, a student asked him directly, 'What tribe are you? I've never seen somebody [who looks] like you.' Alier was initially open about his identity and status, but later became more discerning in what he revealed. Studying outside Turkana County was also eye opening for a number of youth who came to understand the historical marginalization and entrenched beliefs about the inferiority of Turkana people. As some claimed to be Turkana in order to locate themselves within the Kenyan imaginary, they soon realized that this was not an advantageous position. Diane remembered, 'I told them that I came from Turkana County... They used to talk like Turkana is not a part of Kenya.' Rebecca similarly shared, 'They had not heard of this Turkana place. So I said ok, that's where I am from...[According to them] it was not good ... to be from this place, but I thought it is better they think I am Turkana... than refugee.' Protection and security emerged as important dimensions of living outside camps — in particular for Somali refugees. The bounded environment of secondary boarding schools mediated these experiences, and in some cases affiliation with a school served to offset one's risks of being a non-citizen. For example, Ibrahim described how his student identification card often prevented police 
harassment. The National school he attended was 'so well known... even police respected me,' when they saw his affiliation. He believed the school was so highly regarded that police concluded he must be a national.

For other students, school served as a temporary space of security, but once classes were dismissed they found themselves living on the streets, unable to eat, or working several jobs in exchange for access to a shared bed. Presumably, the benefits of integrating up to access higher quality education counterbalanced the risks of living outside the camp. Students who attended government schools noted social connections to Kenyans who had helped free them from jail, paid emergency hospital bills, supported further education, offered free housing, bought or shared books and uniforms with them, and connected them to work opportunities. Opportunities to build social networks and capital while integrating up counter - though do not necessarily offset - experiences of discrimination and violence in non-camp spaces.

\section{Discussion and conclusion}

Policies of integration in contexts of exile are relatively new approaches to structurally align school systems with refugees' long-term future pathways and the underlying purposes of education for displaced peoples. Importantly, the policy presumes that the existing national system is worth replicating and expanding (Dryden-Peterson et al., forthcoming). Indeed, most Kenyan schools struggle with quality (Uwezo 2016), an issue echoed across settings where the policy of refugee education is implemented. One might reasonably ask, then, how much is authentically gained by refugees who manage to integrate up? Examining refugee learners' experiences of educational integration reveals that the perceived academic benefits of integrating up often do outweigh the disadvantages of integrating down into camp schools, resulting in more 
individualized and consistent instruction, as well as greater access to resources. The social risks and uncertainty refugees face in non-camp settings are thus rendered worthy of the potential advantages accrued through higher quality education.

The advantages of integrating up over down are widely recognized by policymakers, school-based actors, young people, and their families. However, there is no clear policy vision for transforming the political and social context - such as legal restrictions on refugees' livelihoods, widespread xenophobia, or the quality of education - to expand opportunities for this kind of integration for all young people. Nor are there necessarily shared beliefs about how such a practice of integration might benefit refugee learners whose rights and belonging within Kenya are conditional and temporary. The enactment, implications, and underlying purposes of integration policies imply different pathways toward educational improvement according to different stakeholders, revealing interactions between academic and social dimensions. Multiple interpretations delink structural and sociocultural processes, reinforcing notions of belonging as individualized, irrelevant of structural constraints. These tensions point to important processes prompted by integration policies: states are simultaneously expanding access to education for refugee populations while negotiating educational rights amongst national citizens (Ager and Strang 2008; Stewart and Mulvey 2014; Strang and Ager 2010). Integration policies can thus expose the structural gaps and inequities between identity groups within states, generating awareness of historical marginality of host communities.

Educational integration also takes place against the larger political backdrop of refugee status in Kenya: rising public fears about national security, a recent government directive for urban refugees to return to camps, threats of camp closures, and increased harassment of refugees by state security actors. For refugee youth who have, through schools, integrated up or 
down, this context does not inspire the intended stability of a policy of integration, but rather contributes to on-going disruptions in youth development (Bellino in press). Many students engage in processes of continual migration, both for protection and in pursuit of educational and work opportunities to enable their integration up: migrating to Kenya, within Kenya, and for the prospect of resettling or repatriating. Young people's educational experiences reveal the ways in which the pursuit of opportunities in the long-term and short-term may entail working at crosspurposes, especially as young people view education as essential to opportunities for mobility and belonging (see also Dryden-Peterson et al, forthcoming; Chopra, 2018).

The policy of integration can be conceived as a symbolic gateway to Kenyan society for refugees, but any attempt to integrate in segregated settings will inevitably encounter limitations. Scholars have long critiqued encampment policies for "warehousing" refugees, resulting in lost human potential and deeper societal division and exclusion. Segregation, isolation, and containment are essential qualities of refugee camp settings, and this physical and symbolic separation from the national population and state services communicates spatial, temporal, and social restrictions on refugees' potential futures in the host country context. Recognizing the centrality of refugees' struggles to achieve social connection and a sense of belonging in their host country have led to recommendations that policy "pull people into the centre rather than polarise and exclude" (Hovil 2016, 200). In theory, integration policies aim to pull refugees "into the centre," yet the ways that these policies are enacted and experienced within national contexts are not always aligned with their intended goals. Kakuma youth experiences challenge the notion that integration policy as implemented is a marker of, or a means to, sociocultural integration, revealing a number of challenges encountered by refugees particularly in camp environments. 
Further, this study foregrounds the need to wrestle with competing visions of integration and the effects they have on the lived experiences of refugees, both real and imagined. These findings beg the important policy question of whether and how educational integration could be a driver of structural and sociocultural integration for all refugee young people, rather than a reflection of the status quo limitations placed on refugees' rights and belonging. In the more immediate-term, our study cautions that policy efforts to structurally integrate Kenyan teachers, curriculum, assessments, and accreditation to camp schools not distract from the equally important need to make the education that is available to refugee young people relevant to their integration experiences and opportunities. Over the longer-term, our study suggests the need for further research on, and policy attention to, connections between increased opportunities for refugees and nationals, tackling inequities that perpetuate the existence of the downward spaces that both refugees and marginalized nationals occupy within the nation-state.

\section{Notes}

1. Colloquially, public, government-run schools located outside Kakuma Refugee Camp are often referenced as 'national schools,' distinguishing them from 'refugee' or 'camp schools.' The Kenyan educational system differentiates between four types of schools at National, Extra-County, County, and Sub-County levels. For clarity, we refer to National schools only when referencing one of the 103 'centres of education excellence,' i.e., the most elite of the four types of schools. In this text, schools located outside the camp are referred to as government schools, with rural/ urban and other descriptors when available.

\section{References}


Abu El-Haj, Thea. 2015. Unsettled belonging: Educating Palestinian American youth after 9/11. Chicago: University of Chicago Press.

Ager, Alistair, and Alison Strang. 2008. "Understanding Integration: A Conceptual Framework." Journal of Refugee Studies 21 (2):166-191.

Alba, Richard D., and Victor Nee. 2003. Remaking the American mainstream : Assimilation And Contemporary Immigration. Cambridge, MA: Harvard University Press.

Alba, Richard, and Nancy Foner. 2014. "Comparing Immigrant Integration in North America and Western Europe: How Much Do the Grand Narratives Tell Us?" International Migration Review 48 (s1):S263-S291.

Aukot, Ekuru. 2003. " 'It is better to be a refugee than a Turkana in Kakuma': Revisiting the relationship between hosts and refugees in Kenya." Refuge 21 (3):73-83.

Bajaj, Monisha, Melissa Canlas, and Amy Argenal. 2017. "Between rights and realities: Human rights education for immigrant and refugee youth in an urban public high school." Anthropology and Education Quarterly 48 (2):124-140.

Bajaj, Monisha, and Lesley Bartlett. 2017. "Critical transnational curriculum for immigrant and refugee students." Curriculum Inquiry 47 (1):25-35.

Bartlett, Lesley. 2015. "Access and Quality of Education for International Migrant Children." Background paper prepared for the Education for All Global Monitoring Report 2015. Education for All 2000-2015: Achievements and Challenges.

Bartlett, Lesley, and Ameena Ghaffar-Kucher. 2013. "Introduction." In Refugees, immigrants, and education in the Global South: Lives in motion, edited by Lesley Bartlett and Ameena Ghaffar-Kucher, 1-21. New York: Routledge. 
Bellino, Michelle J. In press. "Youth Aspirations in Kakuma Refugee Camp: Education as a Means for Social, Spatial, and Economic (Im)mobility." Globalisation, Societies, and Education.

Bray, Mark. 2009. Confronting the shadow education system: What government policies for what private tutoring? Paris: UNESCO-IIEP.

Callahan, Rebecca M., Chandra Muller, and Kathryn S. Schiller. 2008. "Preparing for Citizenship: Immigrant High School Students' Curriculum and Socialization." Theory and Research in Social Education 36 (2):6-31.

Capps, Randy, and Kathleen Newland. 2015. The Integration Outcomes of U.S. Refugees: Successes and Challenges. Washington, DC: Migration Policy Institute.

Chopra, Vidur. 2018. Learning to Belong, Belonging to Learn: Syrian Refugee Youths' Pursuits of Education, Membership and Stability in Lebanon. (EdD), Harvard University, Cambridge, MA

Dryden-Peterson, Sarah. 2011. Refugee Education: A Global Review. Geneva: UNHCR.

Dryden-Peterson, Sarah, Elizabeth Adelman, Michelle J. Bellino, and Vidur Chopra. Forthcoming. "The Purposes of Refugee Education: Policy and Practice of Integrating Refugees into National Education Systems."

Dryden-Peterson, Sarah, Negin Dahya, and Elizabeth Adelman. 2017. "Pathways to educational success among refugees: Connecting local and global resources." American Educational Research Journal.

Dryden-Peterson, Sarah, and Lucy Hovil. 2004. "A Remaining Hope for Durable Solutions: Local Integration of Refugees and their Hosts in the Case of Uganda." Refuge 22:26-38. 
Epstein, Andrew I. 2010. "Education refugees and the spatial politics of childhood vulnerability." Childhood in Africa 2 (1):16-25.

Gilmore, Ruth Wilson. 2011. "What is to be done?" American Quarterly 63 (2):245-265.

Gordon, M.M. . 1964. Assimilation in American Life. New York: Oxford University Press.

Hertzberg, Fredrik. 2015. "Double gestures of inclusion and exclusion. Notions of learning outcomes, autonomy, and informed choices in Swedish educational and vocational guidance." International Journal of Qualitative Studies in Education 28 (10):1203-1228.

Horvat, Erin McNamara, Elliot B. Weininger, and Annette Lareau. 2003. "From Social Ties to Social Capital: Class differences in the relations between schools and parent networks." American Educational Research Journal 40 (2):319-351.

Hovil, Lucy. 2016. Refugees, conflict and the search for belonging. Palgrave Macmillan.

Human Rights Watch. 2002. "Hidden in Plain View: Refugees Living Without Protection in Nairobi and Kampala." New York: Human Rights Watch.

Jensen, Lene Arnett, and Constance A. Flanagan. 2008. "Immigrant Civic Engagement: New Translations." Applied Developmental Science 12 (2):55-56.

Jurado, Elena. 2008. Citizenship: Tool or Reward? The Role of Citizenship Policy in the Process of Integration. London, UK: Policy Network Paper.

Kagwanja, P. M., E. Odiyo, and P.O. Ndege. 2001. Urban Refugees in Kenya: A Review of the Literature. Nairobi,, Kenya: Moi University Centre for Refugee Studies.

Karam, Fares J., Christine Monaghan, and Paul J. Yoder. 2016. "The students do not know why they are here': Education decision-making for Syrian refugees." Globalisation, Societies and Education:1-16. 
Karanja, L. 2010. "The educational pursuits and obstacles of urban refugee students in Kenya." International Journal of Cross Disciplinary Subjects in Education 1 (3):147-155.

Kennelly, Jacqueline, and JoAnne Dillabough. 2008. "Young people mobilizing the language of citizenship: struggles for classification and new meaning in an uncertain world." British Journal of Sociology of Education 29 (5):493-508.

Kenya National Bureau of Statistics, and Society for International Development - East Africa. 2013. Exploring Kenya’s Inequality Pulling Apart or Pooling Together? Nairobi, Kenya: Kenya National Bureau of Statistics and Society for International Development - East Africa.

Kenya, Republic of. 2012. Task Force on the Re-Alignment of the Education Sector to the Constitution of Kenya 2010. Nairobi, Kenya: Ministry of Education.

Korac, Maja. 2003. "Integration and How We Facilitate It: A Comparative Study of the Settlement Experiences of Refugees in Italy and the Netherlands." Sociology 37:51-68.

Koyama, Jill P. 2013. "Resettling notions of social mobility: locating refugees as 'educable' and 'employable'." British Journal of Sociology of Education 34 (5-6):947-965.

Kurban, Fikriye, and Joseph Tobin. 2009. "‘They Don't like Us': Reflections of Turkish Children in a German Preschool." Contemporary Issues in Early Childhood 10 (1):24-34.

Lewin, Keith M. 2009. "Access to education in sub-Saharan Africa: patterns, problems and possibilities." Comparative Education 45 (2):151-174.

Lewin, Keith M., and Ricardo Sabates. 2012. "Who gets what? Is improved access to basic education pro-poor in Sub-Saharan Africa?" International Journal of Educational Development 32 (4):517-528. 
Lucas, Adrienne M., and Isaac M. Mbiti. 2012. "Access, Sorting, and Achievement: The ShortRun Effects of Free Primary Education in Kenya." American Economic Journal: Applied Economics 4 (4):226-253.

Maber, Elizabeth J. T. . 2016. "Cross-border transitions: navigating conflict and political change through community education practices in Myanmar and the Thai border." Globalisation, Societies and Education 14 (3):374-389.

McCarthy, Cameron, Goli Rezai-Rashti, and Cathryn Teasley. 2009. "Race, Diversity, and Curriculum in the Era of Globalization." Curriculum Inquiry 39 (1):75-96.

Mendenhall, Mary, Lesley Bartlett, and Ameena Ghaffar-Kucher. 2017. "“If you need help, they are always there for us": Education for Refugees in an International High School in New York City." Urban Review 49 (1).

Milbourne, Linda. 2002. "Unspoken Exclusion: Experiences of continued marginalisation from education among 'hard to reach' groups of adults and children in the UK." British Journal of Sociology of Education 23 (2):287-305.

Morrice, Linda. 2017. "British citizenship, gender and migration: the containment of cultural differences and the stratification of belonging, ." British Journal of Sociology of Education 38 (5):597-609.

Murnane, R. J., and A. J. Ganimian. 2014. Improving Educational Outcomes in Developing Countries: Lessons from Rigorous Evaluations. In National Bureau of Economic Research Working Paper. Cambridge: NBER.

Myers, John E., and Husam A. Zaman. 2009. "Negotiating the Global and National: Immigrant and Dominant-Culture Adolescents' Vocabularies of Citizenship in a Transnational World." Teachers College Record 111 (11):2589-2625. 
Nunn, Caitlin, Celia McMichael, Sandra M. Gifford, and Ignacio Correa-Velez. 2015. "Mobility and security: The perceived benefits of citizenship for resettled young people from refugee backgrounds." Journal of Ethnic and Migration Studies:1-18.

Park, Robert Ezra, Ernest Watson Burgess, Roderick Duncan McKenzie, and Louis Wirth. 1925. The city. Chicago: The University of Chicago Press.

Pavanello, Sara, Samir Elhawary, and Sara Pantuliano. 2010. Hidden and exposed: Urban refugees in Nairobi, Kenya. London: Overseas Development Institute, Humanitarian Policy Group.

Paviot, Laura, Nina Heinsohn, and Julia Korkman. 2008. "Extra tuition in Southern and Eastern Africa: Coverage, growth, and linkages with pupil achievement." International Journal of Educational Development 28 (2):149-160.

Pinson, Halleli, Madeleine Arnot, and Mano Candappa. 2010. Education, Asylum and the 'Noncitizen' Child: The Politics of Compassion and Belonging New York, NY: Palgrave Macmillan.

Portes, Alejandro. 1998. "Children of Immigrants: Segmented Assimilation and Its Determinants." In The Economic Sociology of Immigration, edited by Alejandro Portes, 248-279. New York, NY: Russell Sage Foundation.

Portes, Alejandro, and Rubén G. Rumbaut. 2001. Legacies: The story of the immigrant second generation. Berkeley, CA: University of California Press.

Portes, Alejandro, and Min Zhou. 1993. "The new second generation: Segmented assimilation and its variants." Annals of the American Academy of Political Science 530:74-96.

Rosaldo, Renato. 1994. "Cultural citizenship and educational democracy." Cultural Anthropology 9 (3):402-411. 
Stewart, Emma, and Gareth Mulvey. 2014. "Seeking Safety beyond Refuge: The Impact of Immigration and Citizenship Policy upon Refugees in the UK." Journal of Ethnic and Migration Studies 40 (7):1023-1039.

Strang, Alison, and Alistair Ager. 2010. "Refugee Integration: Emerging Trends and Remaining Agendas." Journal of Refugee Studies 23 (4):589-607.

Th. Jansen , N. Chioncel \& H. Dekkers. 2006. "Social cohesion and integration: learning active citizenship." British Journal of Sociology of Education 27 (2):189-205.

UNHCR. 2012. Education Strategy 2012-2016. Geneva: UNHCR.

UNHCR. 2017. Global Trends: Forced Displacement in 2016. Geneva: UNHCR.

Uwezo. 2016. Are Our Children Learning? Uwezo Kenya Sixth Learning Assessment Report. Nairobi, Kenya: Twaweza East Africa.

Waters, Mary C., and Tomás Jiménez. 2005. "Assessing Immigrant Assimilation: New Empirical and Theoretical Challenges." Annual Review of Sociology 31:105-125.

Waters, Mary C., Van C. Tran, Philip Kasinitz, and John H. Mollenkopf. 2010. "Segmented Assimilation Revisited: Types of Acculturation and Socioeconomic Mobility in Young Adulthood." Ethnic and Racial Studies 33 (7):1168-1193. 